\title{
“War-on-Terror" Frames of Remembrance: The 1985 Air India Bombings After 9/11
} Angela Failler

\begin{abstract}
This paper critically analyzes Canadian filmmaker Sturla Gunnarsson's documentary Air India 182 in light of recent official efforts to remember and redress the 1985 Air India bombings. The author argues that the film, in line with official efforts, constructs a narrative of the bombings through a "war on terror" framing of remembrance that is at once specific to the recircuitries of race produced in the anxious aftermath of 9/11, and consistent with historically rooted operations of xenophobia and colonial power. The significance of such a framing is that it works not only to shape memory of the bombings as a certain kind of event (one with unambiguous perpetrators, victims and damages), it narrows the field of what are imagined as possible actions toward redressing or compensating for its losses. In other words, a war-on-terror framing of remembrance, as a discursive strategy or approach to "remembering" the bombings, limits the potential for a complex 253 understanding of the politics out of which this event arose, restricting public debate over the kinds of responses that continue to be generated in its aftermath. Moreover, a war-on-terror framing of remembrance is understood here to employ neoliberal and settler-colonialist discourses of productive futurity and multicultural tolerance to make remembrance of the bombings concomitant with the construction of turbaned Sikhs and other racially and religiously minoritized citizens as "dangerous internal foreigners." As such, this paper bears implications beyond the documentary film, including the consequences of neoliberalism for the formation of public memory and for the making of race and nation in Canada.
\end{abstract}

\section{Résumé}

Cet article analyse de façon critique le documentaire Air India 182 du cinéaste canadien Sturla Gunnarsson à la lumière des récents efforts officiels de commémorer et de réparer l'attentat à la bombe du vol d'Air India en 1985. L'auteur soutient que le film, en accord avec les efforts officiels, élabore un récit des attentats par le biais d'un cadre de commémoration emprunté à la « guerre contre la terreur, » qui est à la fois propre aux redéfinitions de la race suscitées par l'angoisse à la suite de 9/11, et conforme aux opérations de xénophobie et de puissance coloniale historiques. L'importance d'un tel cadre est qu'il fonctionne non seulement pour façonner le souvenir des attentats comme un certain type d'évènement (dont il n'y a aucune ambigüité quant aux auteurs, victimes et indemnités), mais il restreint le champ de ce que l'on imagine comme des actions possibles visant la réparation ou la compensation pour ces pertes. Autrement dit, en empruntant le cadre de commémoration de la «guerre contre la terreur », en tant que stratégie discursive ou approche à la « remémoration » des attentats à la bombe, on limite le potentiel pour une compréhension approfondie de la politique de laquelle cet événement a émané, restreignant le débat public sur les types de réponses qu'il continue à susciter. De plus, le cadre " guerre contre la terreur » de la commémoration est entendu ici comme employant des discours d'avenir productif et de tolérance multiculturelle appartenant au néolibéralisme et à la colonie de peuplements pour rendre la commémoration des attentats concomitante avec la construction du 
Sikh à turban et d'autres citoyens minoritisés aux niveaux racial et religieux en tant que des « étrangers internes dangereux. » Comme tel, la portée de cet article va au-delà du documentaire, incluant les conséquences du néolibéralisme pour la formation de la mémoire publique ainsi que l'élaboration de la race et la nation au Canada.

KEYWORDS: Air India Flight 182; documentary film; public memory; 9/11; war on terror; turban profiling

Submitted to TOPIA, Volume 27, 2012

The 1985 Air India bombings are a traumatic history that continues to be forgotten in the Canadian story in many ways, but have nevertheless drawn a conspicuous surge of official attention over the past few years. A three-year federal inquiry into the investigation of the bombings beginning in 2006 produced 218 witness testimonies and a nine-volume, 3,864-page report of findings and recommendations regarding the state management of terrorism in Canada. Since 2007, three new government-sponsored public memorial sites dedicated to those killed in the bombings have been unveiled in Toronto, Vancouver and Montreal. Also in 2007, Canadian Prime Minister Stephen Harper declared June 23, the anniversary date of the bombings, a "national day of remembrance for victims of terrorism" (Harper 2007). On the twenty-fifth anniversary of the bombings in 2010, at a commemoration ceremony in Toronto's Humber Bay Park, the prime minister offered an official apology to the relatives of those who were killed, characterizing the bombings as "the single worst act of terrorism in Canadian history" (Harper 2010). Most recently, at an unveiling of the Monk Island memorial site in Montreal in June, 2011, Harper announced the establishment of a five-year, ten-million-dollar counter-terrorism initiative named "The Kanishka Project" after the ill-fated Air India Flight 182, which saw 329 passengers and crew to their death, the majority of whom were Canadian citizens (CBC, June 23, 2011).

Amid these official efforts, Canadian filmmaker Sturla Gunnarsson's documentary Air India 182 (2008) was released. The documentary is not "official" in the sense of being government-issued, but it was financially supported and licensed by Canada's national public television and radio broadcaster, the Canadian Broadcasting Corporation (CBC), and endorsed as "the definitive film about the Air India tragedy" (Gunnarsson 2008a). In other words, the documentary has been taken up as an authoritative account. In her book on the politics of terror and loss, E. Ann Kaplan argues that it is important to pay attention to such accounts, especially given that, for most people, traumatic events such as terrorist attacks are only ever encountered "vicariously" through the media rather than through first-hand witnessing (Kaplan 2005: 87). Media portrayals come to inform our understandings of these events in the absence of other, "closer" encounters, which is precisely what makes Gunnarsson's documentary an influential text; for the majority of audiences who would be second-hand witnesses, the film promises to refresh national memory of 
a tragedy that occurred more than twenty-five years ago with a retrospective of "what really happened."

The film also constructs a specific impression of the political stakes that a history of the Air India bombings raise for the present. Yet reviewers have entirely failed to acknowledge this historical impression as a construct and instead unanimously applaud the film as "a brilliant narrative that says the story as it happened" (Sayeed 2011, emphasis added). Critically analyzing Air India 182 in light of recent official efforts to remember and/or redress the bombings reveals that the film does not simply "say the story as it happened" but produces a version of the past through particular, strategic framings informed by broader political context and ideologies. That is, the documentary produces a narrative of the Air India bombings through a "war-on-terror" framing of remembrance that reiterates hegemonic neoliberal ideologies of national belonging, citizenship, terrorism and security. The significance of such a framing is that it works to shape the memory of the bombings as a certain kind of event - one with unambiguous perpetrators, victims and damages - and narrows the field of what are imagined as possible actions toward redressing its losses. In other words, a war-on-terror framing of remembrance, as a discursive strategy or approach to "remembering," limits the potential for a complex understanding of the politics out of which the event of the bombings arose, restricting public debate over the kinds of responses that continue to be generated in its aftermath. ${ }^{1}$

This argument builds on others I have established previously, namely: that the 1985 Air India bombings are being strategically remembered in the present in order to justify a racist mandate of state securitization as the only "reasonable response" to terrorist threat; that this strategic remembering also functions to distract from the well-documented implication of the Canadian state and its security agencies in the injustices associated with the bombings; and that gestures to "remember" carried out by public authorities in the context of official memorials and processes can be seen as defensive reaction-formations against the charge that systemic racism played a role in the state's belated, failed responses to the fatal disaster (Failler 2009, 2010). In the present article I extend these arguments through an analysis of Gunnarsson's documentary in order to focus more closely on how the bombings are constructed retrospectively through a "war-onterror" framing of remembrance that relies on settler-colonialist discourses of productive futurity and multicultural tolerance as they are articulated in the post-9/11 moment. More specifically, I demonstrate how these ideological formations are being employed to make remembrance of the bombings concomitant with the construction of turbaned Sikhs and other racially and religiously minoritized citizens as "dangerous internal foreigners" (Dhamoon and Abu-Laban 2009). In doing so, this paper reaches beyond the film itself to the consequences of neoliberalism for the formation of public memory, and for the making of race and nation in Canada.

\section{Opening the Film}

Sturla Gunnarsson is an award-winning Canadian filmmaker and director of both documentary and television drama (Gunnarsson 2012). His feature-length Air India 182 premiered at the Hot Docs Canadian International Documentary Festival in Toronto in April 2008. The film was selected as the 2008 festival's Canadian opening presentation and received critical acclaim in subsequent reviews. 2 Shortly after its premiere at Hot Docs, the film aired on public television as part of Doc Zone, the CBC's flagship documentary series, which promotes itself as bringing 
audiences a "panoramic view of what matters most to Canadians" (Doc Zone: About the Series 2012).

For its debut broadcast on June 22, 2008, the twenty-third anniversary of the flight's departure, the Canadian Broadcasting Corporation (CBC) screened Air India 182 without commercial breaks. The host of Doc Zone, celebrated Canadian author, playwright and actor Ann-Marie MacDonald, introduced the film with the following dramatic preamble:

What really happened twenty-three years ago tonight? When Air India Fight 182 blew up, all three hundred and twenty-nine aboard were killed. Most of the victims were Canadian. The crime lead to our legal system's longest-ever investigation. Using CSIS wiretaps, transcripts and interviews, acclaimed director Sturla Gunnarsson presents a chilling account of the worst mass murder in Canadian history. (quoted in Gunnarsson 2008a)

MacDonald's introduction is noteworthy not only for how it frames the Air India bombings as a particular kind of event - "the worst mass murder in Canadian history"-but for how it constructs Gunnarsson's film as a particular kind of account. Opening with the provocation, "What really happened twenty-three years ago tonight?," she sets the film up to provide a definitive answer; audiences are about to learn the truth about the Air India bombings (quoted in Gunnarsson 2008a, emphasis added). MacDonald's reference to Gunnarsson's source materials also aims to secure the film's legitimacy; by claiming that the documentary, like a government report or legal process, is based on officially procured, material evidence, MacDonald tells audiences that they can expect access to the "real" of this history. From the start, Doc Zone's framing works to present the film as matter-of-fact, obscuring its status as a mediated account of history arrived at through strategic processes of selection and arrangement.

The film is shot primarily in high-definition video, incorporating archival materials, such as rarely shown news footage of the accident scene in the Atlantic Ocean off the coast of Cork, Ireland, in which bodies are recovered by rescue crews. Its realist documentary aesthetic is enhanced by interviews with rescue crew, airport personnel, retired members of the Royal Canadian Mounted Police (RCMP) and Canadian Security and Intelligence Service (CSIS), and relatives of those who were killed in the bombings. These interviews make up much of the film's content, and are the basis on which the producers of the film assert that the documentary constitutes "a first person account... as told by those who were directly involved" (Air India 182: A film by Sturla Gunnarsson 2012). Even in the most avowedly fictive layer of the filmdramatic re-enactments by actors playing out goodbyes between family members at the airport, or mimicking the covert activities of terrorist suspects and police investigators-interview voiceovers retain the production's truth value. Moreover, the invisibility of the documentarian, who never appears visually and is scarcely heard asking the interviewees questions, works to uphold a sense that the film is told from a neutral "perspective of nowhere" (Haraway 1994: 115-16). In other words, the illusion of the absent documentarian creates the sense that the content speaks for itself, or "says the story as it happened," (Sayeed 2011, emphasis added), and obscures the ways in which the film is edited from a specifically situated point of view.

The film opens with a dramatization of Shannon airport traffic controller Mike Quinn tracking Flight 182 on his radar screen until it mysteriously disappears. An original tape of static-laden 
communications between Quinn and the flight's pilot recorded moments before the plane went missing is played over this re-enactment. In interview, the now-retired controller laments his failed attempts to re-establish contact with the doomed flight. The film then flashes back to the hours preceding the flight's departure out of Toronto and then Montreal, and the first of several airport goodbye stories told by Vancouverite Mandip Singh Grewal, who was a child when his father left on Flight 182 to visit his ailing grandmother in India. Grewal's account, accompanied by a re-enactment of his father's send-off at the departure gate, is overlapped by the first of several expositions by Canadian police authorities on their investigation of Babbar Khalsa, the "militant Sikh extremist organization" understood to be responsible for the Air India bombings. The remainder of the film unfolds this way, suspensefully counting down to Flight 182's demise through the interweaving of archival materials, interviews, re-enactments and voiceovers.

\section{Grieving Subjects and Reasonable Men}

At first glance, it would appear that a diversity of voices is represented by the film through its inclusion of nearly two dozen interviewees. Upon closer inspection, however, it seems that the interviewees occupy one of two roles, with little exception: grieving subjects or reasonable men. Each interviewee tells a story of his or her relationship to the events surrounding the bombings and to those who were killed. I do not mean to under-represent the nuances of these individual accounts, and yet distinct patterns emerge. Airline employees recall, with fresh heartache and regret, memories of meeting passengers and processing luggage to board Flight 182. With obvious, lingering sorrow and in graphic detail, rescue workers recall their recovery efforts subsequent to the crash. The relatives of those killed, who are primarily Canadian citizens of Indian origin, tell stories replete with excruciating, palpable grief and sentiment. Strikingly, many intuited that "something wasn't quite right" when saying their good-byes with loved ones at the airport. Others remember how, upon hearing the declaration of "no survivors," they nevertheless hoped that their own family members were saved or swam safely to shore.

These grieving subjects and the narratives they offer stand in dramatic contrast to the representation of retired RCMP and CSIS agents in the film. The agents tell a story of a manhunt foiled, not by the terrorist suspects themselves, nor by their own agencies' communication problems and mishandling of evidence, but ultimately by a lack of resources. Former CSIS deputy director Jack Hooper is confident of this: "The more resources that you have working against the target, the greater the prospect that you're going to find that critical 'nugget,' that very valuable singular piece of intelligence, 'actionable intelligence,' if you will' (quoted in Gunnarsson 2008a). Even while admitting to certain "mistakes," such as erasing wiretap recordings of key suspects, the RCMP and CSIS are cast as insisting on the capacity of their agencies to ensure security above all else. The film conveys that an event such as the Air India bombings would never have happened if only more resources had been directed toward policing agencies and their anti-terrorist security efforts.

The narrations by RCMP and CSIS members also function within the film to establish the "reality" of the history of the bombings. An exception is Ujjal Dosanjh, a member of Parliament and a former premier of British Columbia, who notes the general indifference of Canadian public officials to conflicts that were manifesting in South Asian diasporic communities prior to the bombings. In Dosanjh's words: "You know, here were some brown guys, some with turbans, 
others without turbans, killing each other or hurting each other or making fiery speeches about something that was 15,000 miles away. It didn't affect anybody else in the society; it doesn't matter" (quoted in Gunnarsson 2008a). Aside from Dosanjh, the exclusively white, male RCMP and CSIS agents are the only voices in the documentary providing analysis of the Air India bombings as a historical event. They are positioned as reliable historians, most able to make sense of the disaster. Moreover, they are positioned as knowing best what a "reasonable response" to terrorism looks like. Recalling transcripts of coded language allegedly used among the suspected terrorists, Hooper asks, "What does that mean to you as a reasonable man?... That doesn't follow in any reasonable man's reality" (quoted in Gunnarsson 2008a). Hooper's rhetorical question leaves little ambiguity as to whose version of events commands symbolic authority in accounting for this history.

\section{Turban Profiling and "the Face of Terror"}

"Reasonable men" in Air India 182 are not only constructed in opposition to grieving subjects but also, perhaps more predictably, to terrorist suspects. This construction is accomplished mainly through framings used to distinguish the "face of terror" from that of the "regular," benevolent Canadian. Turban profiling, I argue, is central to this framing. In " The Turban is Not a Hat': Queer Diaspora and Practices of Profiling" (2008), Jasbir Puar contemplates the dramatic increase in violent hate crimes against turbaned Sikh men in the United States since 9/11. Other scholars have noted a similar impact in the Canadian Sikh diaspora (Thobani 2007: 239; Verma 2006: 92). Puar discusses how these incidents have been interpreted as cases of "mistaken identity," in which perpetrators mistook their victims for their intended targets: Muslim terrorists believed to be responsible for the World Trade Centre attacks (2008: 55-62). For Puar, however, these are not so much cases of misrecognition as they are occasions where Sikh men served as adequate substitutes for the elusive Osama bin Laden (62); that is, committing violence against anonymous, turbaned brown bodies was good enough to quell the aggressive affects of the perpetrators. According to Puar, these attacks are evidence of how, under the dominant gaze since 9/11, the significance of the turban has indiscriminately shifted from a marker of religious, cultural or regional specificity to accrue monolithic status as a symbol of terrorist masculinity and a threat to national security (54).

"Reading turbans through affect" as Puar does, helps to reflect on Gunnarsson's portrayal of terrorist subjects and the potential impact of these racialized representations in an era of "turban profiling" $(47,58)$. Turban profiling is cultivated scene after scene in the film, as bearded, turbaned, South Asian male actors playing terrorist suspects lurk in airports, speak coded Punjabi in mysterious phone calls to one another, and practice detonating explosives in the woods. Archival footage shows protest rallies in Vancouver, where crowds of turbaned Khalistani supporters cry for bloody revenge after masses of Sikhs were murdered by the Indian army in the 1984 Operation Blue Star raid on the Sikh Golden Temple in Amritsar, India. Camera shots repeatedly zoom in on, pan around and freeze upon the figure of Talwinder Singh Parmar, leader of the Babbar Khalsa in Vancouver and the suspected "mastermind" of the Air India attacks, whose especially elaborate, brightly coloured pagh (turban) is framed so as to familiarize the viewer with the "face of the enemy."

Amid these representations, Gunnarsson includes an interview with Kawant Singh Mamak, 
whose wife was killed on Flight 182. Along with other relatives of the victims, Mamak arrived in Cork immediately after the crash. In the film, he recalls, "They were looking at me saying, "the Sikhs did it,' and I was one of the persons that was wearing a turban.... These people [were] saying...' 'you guys did it, you guys did it,' and I had to tell them that 'I lost my wife too"' (quoted in Gunnarsson 2008a). Although Mamak's recollection may have been included in the film precisely to mitigate the collapsing of all turbaned Sikh subjects into the category "terrorist," on an affective level, the film still overwhelms with examples of this categorization, particularly since, as the post-9/11 hate crimes in Puar's study suggest, "the turbaned Sikh is [now] always already circumscribed as a dangerous terrorist look-alike or aspirant terrorist" (2008: 59). While there are other non-turbaned Sikhs among the interviewees, Mamak and two others in the film - Flight 182 co-pilot Satwinder Singh Bhinder and Montrealer Harinder Marjara, who lost his wife, Devinder, and daughter Seema-remain exceptional representations of non-terrorist turbaned Sikh men among the dozens of portrayals of turbaned terrorist suspects that pepper the documentary.

\section{"Dangerous Internal Foreigners" Vs. "Good Immigrants"}

Narratives of the Air India bombings constructed through a war-on-terror framing of remembrance are particular to the recircuitries of race that have been produced in the anxious aftermath of 9/11, and consistent with historical operations of xenophobia and colonial power. In other words, this framing takes advantage of the ways in which Sikhs have been collapsed into the category "terrorist" in the post-9/11 context of intensified hostility toward Muslims and racialized "others who resemble them" (Verma 2006: 90), while drawing on histories of Sikhs cast as threats to the nation. In her report as an expert witness for the Air India inquiry, University of Toronto sociologist Sherene Razack cites the Komagata Maru incident as an example of such a history that precedes both 9/11 and the 1985 Air India bombings by decades. In 1914, Canadian officials forcefully turned away the Komagata Maru, a shipload of mostly Sikh men from India wishing to settle in Canada, many of whom consequently died. The officials justified the action by the same time she would never tell anyone she's a doctor, unless it came up or anything. She was the most humble person I know" (quoted in Gunnarsson 2008a). Lata Pada, who lost her husband, Vishnu, and two daughters, Brinda and Arti, recollects, "We had two very talented young daughters, and my life revolved around my family. It was our hope that they would grow up to be really productive, good Canadians" (quoted in Gunnarsson 2008a). In contrast, bad immigrants in the film are portrayed as terrorists who use the country's resources to fuel their own separate/separatist agendas; they seek "terrorist financing" instead of contributing to the future of the nation.

That the filmmaker chose to feature these and similar stories as a way of representing the lives of those who were killed in the bombings reveals much about the ideological underpinnings of the film; these stories construct not only a particular version of the Air India bombings, but a particular version of social reality in Canada. The film can be seen as working to construct "proof" of Canada as a benevolent host country that is welcoming of immigrants: "Witness our model minorities! Canada is multicultural and tolerant." This framework of benevolence becomes the basis for upholding the predominant image of Canada as an "innocent nation outside of history [and violence]" (Razack 2007: 6), save for intrusion by bad immigrants or murderous Others from elsewhere, as in the instance of the Air India bombings. 
Prime Minister Stephen Harper mirrors this image during his so-called apology to the relatives of those killed in the bombings at the twenty-fifth anniversary memorial in Toronto:

It is incumbent upon us all not to reach out to, but rather to carefully and systematically marginalize those extremists who seek to import the battles of India's past here.... We fear that when we invite from around the world those who share our aspirations for a better life, others also come, those who see in our Canada not new bridges to a hopeful future but only another chance to travel the old roads to the blood-feuds of the past.... We must have none of it. Just as we must continue the struggle against destroyers and murderers of all kinds...we must learn how to thwart them. (Harper 2010)

After apologizing in vague terms for "the institutional failings of twenty-five years ago" and the "woeful inadequacy" shown toward the relatives of the victims by agencies of the government of Canada, Harper quickly moves on to this call to national defence (Harper 2010). He makes clear that learning to thwart "destroyers and murderers of all kinds" (Harper 2010) will not be accomplished by dwelling on the government or its agencies' past mistakes or implication in the injustices surrounding the Air India bombings; rather, it will be accomplished by keeping the critical gaze turned outward, organized around feelings of aggressive indignation towards potentially threatening Others. This is to say, it is incumbent upon "us all" to become familiar with the face of terror, and to do so is to recognize those who would snub the benevolent hand of "our Canada" by refusing to assimilate_or "share," as Harper puts it — "our vision" of productive futurity (Harper 2010).

Not only does Harper cross-articulate migration from India with terrorist threat in this speech, he also casts his web of suspicion around the world, for "sadly," he goes on to say, "we have no way of knowing when, if, or how, we may once more be attacked. Or by whom. We know only that terrorism is an enemy with a thousand faces" (Harper 2010). Following 9/11, the phrase "terrorism is an enemy with a thousand faces" was popularized in reference to the Al-Qaeda network to warn of terrorist ontogenesis within contexts of multicultural cosmopolitanism, raising fears that unrestricted transnational migration will breed "evil among us," or "homegrown terrorists" (Noble 2008: 24). Recalling this phrase on this occasion, Harper retroactively frames the Air India bombings through a war-on-terror lens. In doing so, he appropriates memories of 9/11 and the Air India bombings toward a neoliberal vision of the present and future, a hypocritical vision that casts the nation state as inclusive while fostering immigration panic. This vision is used to justify a regime of securitization carried out through discriminatory practices and policies on immigration, citizenship, "foreign" labour, refugee protection, multiculturalism, border security, domestic policing and of course, anti-terrorism, all ostensibly in the name of "prevent[ing] another Flight 182" (Harper 2010).4

Immigration panic, or fear of the elusive "enemy with a thousand faces," is similarly cultivated in Gunnarsson's film as CSIS and RCMP agents describe "the nature of the terrorist beast" (Hooper quoted in Gunnarsson 2008a). In particular, we are to be warned of the terrorist beast's cunning ability to pass as someone who shares our aspirations for a better life; to pass, in other words, as a good immigrant. In the following statement, Doug Henderson, a retired RCMP officer from Duncan, British Columbia, recalls his shifting impressions of bombing suspect Inderjit Singh Reyat, a turbaned Sikh man who Henderson knew as his local auto mechanic prior 
to being assigned to investigate him:

Inderjit Reyat seemed to me like a nice family man. I have five children; I believe he had four children. We seemed to have a lot of the same goals in life, and whatnot. It just seemed to be one of those deals where we just got along well with one another... [But] as the investigation started to unfold, I certainly started to see a different person.... It was a learning curve about terrorism and what a terrorist is really like. (Quoted in Gunnarsson 2008a)

The significance of the inclusion of this interview excerpt in the film can be thought of alongside Homi K. Bhabha's notion of "colonial mimicry" (1994). Colonial mimicry is "the desire for a reformed, recognizable Other, as a subject of a difference that is almost the same, but not quite" (122). In the context of Canadian neoliberal multiculturalism, this desire translates into an imperative for racially minoritized immigrant subjects to make themselves intelligible in terms of economic viability and heteronormative reproductivity without becoming too intelligible so as to become indistinguishable from "regular" citizens; this would threaten the balance of white dominance and make a mockery of the civilizing mission. I argue that this latter possibilitywhat Bhabha might call the "menace of mimicry" (126) — is precisely the threat that Reyat's passing poses. The film, then, works to mitigate this risk of misrecognition, providing lessons in how to distinguish between mimickers and menaces. Markers of difference must be (re)established, distinctions between same-Others and other-Others must be made clear; thus, the film returns us, again and again, to the tell-tale sign of anti-modernity: the turban.

\section{"Made in Canada": Raising the Spectre of Home-Grown Terrorism}

At a key point in the film, Nicola Kelly, the woman I cited above whose mother was killed on Flight 182, recalls the now-infamous response to the bombings from Ottawa in the days following: "I remember then-Prime Minister Brian Mulroney sending his condolences to the Indian government, which was such an outrage to me because...my mother was a Canadian citizen, I'm a Canadian born in this country and yet his condolences are going to India. It's like we were never Canadians in the first place" (quoted in Gunnarsson 2008a). This memory is made particularly significant by the fact that, over the past few years, government authorities have publicly admitted their failing, and the failing of the Canadian public, to recognize that the majority of the victims and their families were Canadian citizens. In a 2005 report titled Lessons to be Learned, Bob Rae pronounced, "Let it be said clearly: the bombing of the Air India flight was the result of a conspiracy conceived, planned, and executed in Canada. Most of its victims were Canadians. This is a Canadian catastrophe" (Rae 2005: 2). In his report on the first phase of the federal commission of inquiry into the investigation of the bombing of Air India flight 182, Commissioner John Major wrote, "in spite of the obvious magnitude of the catastrophe, Canada and Canadians in general did not immediately recognize it as a terrorist attack against Canadians. That acceptance was long in coming" (Major 2008: 2). At a formal unveiling of the Toronto memorial dedicated to those killed in the bombings, Harper made an attempt to lay bare the belatedly acknowledged "facts": "Flight 182 may have flown that fateful day under the flag of India, but the murder of its passengers was singularly a Canadian crime and tragedy. And worst of all, many Canadians didn't realize this until much, much later.... This was a terrible, hurtful mistake. One that Canada will always regret" (Harper 2007). Similarly, during his official apology speech, Harper insisted: "Canadians who sadly did not at first accept that this outrage 
was made in Canada, accept it now. This was not an act of foreign violence. This atrocity was conceived in Canada, executed in Canada, by Canadian citizens, and its victims were themselves mostly citizens of Canada" (Harper 2010).

The inclusion of Kelly's statement in the film seems to be a moment where the documentary, in watchdog-journalism fashion, echoes Kelly's desire to hold the state accountable. But like the apologies and gestures of recognition made by public authorities to date, the film maintains an impression that such "mistakes"-failing to recognize those killed in the bombings or their families as Canadians, and thus failing to provide them with practical supports or public acknowledgment in the days and years to come - had nothing to do with systemic racism or the colonialist perception of whiteness as concomitant with Canadian identity; rather, these mistakes are explained as the result of naïve misrecognitions of cultural difference by otherwise wellmeaning, tolerant folks. The following excerpt from the interview with Henderson perhaps captures this line of self-defence best: "Canadian police agencies [were] in our infancy as far as terrorism investigations [are concerned]. Police officers at the time, I mean, yes, Canada has a great Canadian mosaic today, [but] back in 1985...we didn't know the difference between, uh, what is Punjabi? What is Sikh? What is Hindu? Khalistan? What is that? Where's India?' (quoted in Gunnarsson 2008a). In the context of this intertextual framing, the inclusion of Kelly's memory in the film actually per- forms a function other than critique: alongside Harper's and others' reiterations that the Air India bombings were "made in Canada," the film positions Kelly's statement in such a way as to reiterate the vulnerability of good Canadians at the hands of "home-grown" terrorists. Remembering the bombings as acts of terrorism bred on Canadian soil and committed against Canadian citizens justifies the urgent need for intensified measures of security such as terrorist profiling. Being able to recognize the difference between good immigrants and dangerous internal foreigners will purportedly ensure that our future is protected against any similar harms.

The film concludes with the dramatized capture and interrogation of Reyat, the only suspect in the Air India bombings case who was ever convicted. In the final scene, Henderson is portrayed interrogating Reyat, pressing him to concede that whoever is responsible for the Air India bombings "should be shot" (quoted in Gunnarsson 2008a). I argue that this representation suggests that the reasonable response to terror is violent retribution, the reasonable man's "regime of justice" as it is conveyed throughout the film.5 Although this scene is a dramatized re-enactment, its use of the original interrogation audio recordings and its privileged position as the film's closing image bolster an impression that the question of redress is no more and no less a matter of war on terror(ists). In other words, ending the film with an image of the face of the enemy works to keep the critical gaze turned out- ward and organized around feelings of aggressive indignation toward potentially threatening Others or "foreigners within," rather than upon the Canadian state's own culpability with respect to the injustices surrounding the bombings. In fact, the lesson to be learned from this cautionary tale has little to do with why the Air India bombings were not recognized as a national trauma in the first place, or with what this failure reveals about conceptions of national belonging; rather, the film suggests plainly that Canada needs to get tougher on terrorism.

\section{Cracks in the Frame: Toward a Conclusion}


Reaching toward a conclusion, I want to introduce the special-feature materials included with the DVD release of Gunnarsson's film (Gunnarsson 2008b), which add another interesting layer to be considered. The DVD extras, unavailable to those watching the televised version of the documentary, consist of both archival and new materials including a RCMP recording of Henderson interrogating Reyat, the air-traffic-control tape of communications between Shannon airport and Flight 182, fourteen additional interviews with people who already appear in the film, and nine additional interviews with people who do not already appear in the film. These materials are fascinating as moments in which the documentary objectivity of Air India 182 is potentially cracked through. In other words, they are moments in which the coherence of the narrative framing may be seen to be disrupted by competing images and statements that remain excluded from the film proper, but nevertheless shape the story in their spectral absence. I suggest that these moments have the potential to expose tensions in how the Air India bombings are remembered within and for public discourse, and to reveal inconsistencies between official narratives and the experiences of those intimately involved with the events.

In light of the DVD extras, a set of questions emerges. Why did these extras not make the main cut? How do they disrupt the version of the bombings advanced by the film proper? Might the extras be considered cracks in the frame that allow for a more complex story of the Air India bombings to emerge? An interview with Renée Saklikar, a Vancouver lawyer and poet whose aunt Zebunnisa Jethwa and uncle Umar Jethwa were killed in the bombings, stands out for her passionate criticism of the Canadian justice system's efforts to bring resolution to the case, a criticism that is not given voice in the film itself (Gunnarsson 2008b). Another interviewee, Sodhi Singh Sodhi, stands out not only for being an outspoken Khalistani supporter but also for how, throughout his interview, the voice of director Sturla Gunnarsson can be heard clearly questioning him about his involvements in a political protest that resulted in the invasion of an Indian consulate (Gunnarsson 2008b). Amarjit Bhinder, wife of the co-pilot, Bhinder, begins her interview stating, "I am Sikh and I am proud to be a Sikh.... Sikh religion is a very modern and tolerant religion.... It does not justify innocent killings," going on to confess to Gunnarsson, "It's very painful, very, very painful [to speak about the bombings]. But I didn't want to say no to you, because you are doing this professionally and I didn't want to be rude to you" (quoted in Gunnarsson 2008b). Did certain interviews become "outtakes" because they were considered too political, too painful to watch, too lacking in dramatic effect, too complex, too revealing or too unintelligible? If so, what rendered them as such in the minds of the director, producers or broadcasters?

To me, one of the most striking extras is an interview with Henderson, who is featured throughout the film more or less consistently upholding what I have been calling the reasonable man's version of events. In the extras interview, however, Henderson appears visibly upset, moved nearly to tears in remembering his personal exchanges with the distraught family members of people who were killed in the bombings (Gunnarsson 2008b). He ends his interview by saying, "Policemen usually don't go there," referring to his own emotionality and recognition of its discordance with the stance of unaffected masculinity associated with his professional role, followed by, "It does affect you, yeah" (quoted in Gunnarsson 2008b). Henderson's acknowledgment of affectedness here lingers with me as a crack in the framing of a film in which subjects are otherwise cast into the rather strict roles of grieving subjects, terrorists or reasonable men. Minor as it may seem, especially given its relegation to the "extras," the 
inclusion of this kind of memory has the potential to make more complex the question of who is affected by the Air India bombings and how, and to challenge the ideological separation between "us" and "them" that contributes to the framework of Othering that produces certain racially and religiously minoritized citizens as inherently suspect.

\section{Acknowledgements}

Thanks to Karen Sharma, Amber Dean, Rita Kaur Dhamoon and Ali Kazimi, as well as the anonymous reviewers and editors for helpful comments on draft versions of this article. Thanks also to Roger I. Simon, Parvin Ghoryashi and my research assistants Elan Marchinko and Raena Penner for their particular support of my research. Funding from the Social Sciences and Humanities Research Council of Canada has also made research for this article possible.

\section{Notes}

1. I invoke the terms "event" and "aftermath" in relation to the Air India bombings cautiously here, upon Roger I. Simon's observation that their use assumes we can know what the proper historical context of such an event is, its temporal and spatial boundaries, or the "range and substance of its consequences" (2008 353-54). That is, speaking of the "event" of the bombings or the "aftermath" of the bombings not only performs a delimiting of what counts as integral to this history, it obscures the way in which "event-ness" is produced through our present recollections of this so-called past.

2. For a selection of these reviews see Canadian Press 2008; Dixon 2008; Johnson 2008; Kirkland 2008; Marchand 2008; Sayeed 2011; Tong 2011; and Velayanikal 2011.

3. I am echoing Prime Minister Harper's so-called apology speech, given at the twenty-fifth anniversary memorial ceremony in Toronto and addressed to the relatives of those killed in the Air India bombings, during which he made the following call to national defence, evoking the Air India bombings and the Komagata Maru simultaneously. I make further comment on this speech here as well in "'Remember Me Nought': The 1985 Air India Bombings and Cultural Nachträglichkeit" (Failler 2010).

4. To read more on how this regime of securitization is being carried out since 9/11 in Canada, see Anti-Terrorism: Security and Insecurity after 9/11 (Rollings-Magnusson 2009: 1-31).

5. On the construction of "regimes of justice" in mediatized representations of war and conflict see "The Aestheticization of Suffering on Television" (Chouliaraki 2006).

\section{References}

Air India 182: A film by Sturla Gunnarsson. 2012. http://www.airindia182.com. Bhabha, Homi K. 1994. The Location of Culture. London and New York: Routledge.

CBC. 2011. PM Unveils Fourth Air India Memorial in Montreal: Marks Twenty-Sixth Anniversary of Bombing, CBC News, 23 June. http://www.cbc.ca/news/canada/story/ 
2011/06/23/air-india-memorial.html.

Doc Zone: About the Series. 2012. CBC. http://www.cbc.ca/documentaries/doczone/ about.html.

Chouliaraki, Lilie. 2006. The Aestheticization of Suffering on Television. Visual Communication 5(3): 261-85.

Dhamoon, Rita. 2009. Identity/Difference Politics: How Difference Is Produced, and Why It Matters. Vancouver and Toronto: University of British Columbia Press.

Dhamoon, Rita and Yasmeen Abu-Laban. 2009. Dangerous (Internal) Foreigners and NationBuilding: The Case of Canada. International Political Science Review 30(2): 163-83.

Canadian Press. 2008. Documentary Air India 182 Delves into 1985 Bombing that Killed 329 People, Canadian Press. www.airindia182.com/downloads/CanadianPress.pdf.

Dixon, Guy. 2008. The Heartache Behind the Headlines, Globe and Mail, 17 April. http://airindia182.com/downloads/GlobeMail-GuyDixon.pdf.

Failler, Angela. 2009. Remembering the Air India Disaster: Memorial and Counter- Memorial. The Review of Education, Pedagogy, and Cultural Studies 31(2-3): 150-76.

—. 2010. "Remember me nought": The 1985 Air India bombings and cultural Nachträglichkeit. Public: Art/Culture/Ideas 42: 113-24.

Gunnarsson, Sturla. 2008a. “Air India 182.” Television series episode. Directed by Sturla Gunnarsson. Aired 22 June on Doc Zone, hosted by Ann-Marie MacDonald. Canadian Broadcasting Corporation.

—. 2008b. Air India 182. DVD. Directed by Sturla Gunnarsson. Toronto: 52 Media, Eurasia Motion Pictures, and the Canadian Broadcasting Corporation.

—. 2012. Sturla Gunnarsson Official Web site. http://www.sturlagunnarsson.com/.

Haraway, Donna. 1996. Situated Knowledges: The Science Question in Feminism and the Privilege of Partial Perspective. In Human Geography: An Essential Anthology, edited by John A. Agnew and David J. Livingstone, 108-28. Malden, MA: Blackwell Publishing.

Harper, Prime Minister Stephen. 2007. Prime Minister Unveils Memorial Dedicated to Victims of Air India flight 182. Public address in Toronto, 23 June.

—. 2010. PM Speaks at Commemoration Ceremony for Air India flight 182. Public address in Toronto, 23 June.

Johnson, Brian D. 2008. Air India 182 and the Beauty of Hot Docs, Macleans, 18 April. http://www2.macleans.ca/2008/04/18/air-india-182-and-the-beauty-of-hot-docs/. 
Kaplan, E. Ann. 2008. Trauma Culture: The Politics of Terror and Loss in Media and Literature. New Brunswick: Rutgers University Press.

Kirkland, Bruce. 2008. Air India 182 Opens Hot Docs Fest, Sun Media.

http://jam.canoe.ca/Movies/2008/04/18/5319701-sun.html.

Major, John. 2008. The Families Remember: Phase One Report. Commission of Inquiry into the Investigation of the Bombing of Air India Flight 182. Ottawa: Public Works and Government Services Canada.

Marchand, Phillip. 2008. Tragic Narrative: Sturla Gunnarsson's Documentary Uses Both Victims' Family and Re-Enactments to Tell the Story of Air India Bombing and Investigation, The Star, 16 April. http://www.thestar.com/entertainment/article/414901.

Noble, Greg. 2008. The Face of Evil: Demonising the Arab Other in Contemporary Australia. Cultural Studies Review 14(2): 14-33.

Puar, Jasbir K. 2008. “The Turban Is Not a Hat": Queer Diaspora and Practices of Profiling. Sikh Formations: Religion, Culture, Theory 4(1): 47-91.

Puar, Jasbir K. and Rai, Amit S. 2004. The Remaking of a Model Minority: Perverse Projectiles Under the Specter of (Counter) Terrorism. Social Text 22(3): 75-104.

Rae, Bob. 2005. Lessons to be Learned: The Report of the Honourable Bob Rae, Independent Advisor to the Minister of Public Safety and Emergency Preparedness, on Outstanding Questions with Respect to the Bombing of Air India Flight 182. Ottawa: Air India Review Secretariat.

Razack, Sherene H. 2007. The Impact of Systemic Racism on Canada's Pre-bombing Threat Assessment and Post-bombing Response to the Air India Bombings. Unpublished expert witness report submitted to the commission of inquiry into the investigation of the bombing of Air India flight 182, 12 December.

Rollings-Magnusson, Sandra, ed. 2009. Anti-Terrorism: Security and Insecurity after 9/11. Halifax and Winnipeg: Fernwood Publishing.

Sayeed, Vikhar Ahmed. 2011. Making Sense of a Twenty-Six-Year-Old Tragedy, The Hindu, 21 December. http://www.thehindu.com/news/cities/bangalore/ article2735296.ece.

Simon, Roger I. 2008. Altering the Inner Life of the Culture: Monstrous Memory and the Persistence of 9/11. The Review of Education, Pedagogy, and Cultural Studies 30(3): 352-74.

Tong, Allan. 2008. Air India 182. Hot Docs Review, Exclaim. http://exclaim.ca/Reviews/ HotDocs/air_india_182-sturla_gunnarsson.

Velayanikal, Malavika. 2011. Who Brought Down Air India 182, and How? DNA India, 21 
December. http://www.dnaindia.com/print710.php?cid=1628368.

Verma, Rita. 2006. Trauma, Cultural Survival and Identity Politics in a Post-9/11 Era: Reflections by Sikh Youth. Sikh Formations 2(1): 89-101. 